\section{Serum tri-iodothyronine, thyroxine, and thyrotrophin concentrations in newborns during the first 2 days of life ${ }^{\star}$}

Previous experimental data indicate that the fetal pituitary-thyroid axis functions autonomously and no or only minimal placental transfer of thyroxine $\left(\mathrm{T}_{4}\right)$, tri-iodothyronine $\left(\mathrm{T}_{3}\right)$, or thyrotrophin (TSH) occurs. Human fetal $\mathrm{T}_{4}$ and TSH secretions increase after 18-22 weeks of gestation. Serum $T_{3}$ concentrations are low before the 24th gestational week, but increase progressively thereafter to term (Fisher et al., 1973).

The earlier data on $T_{3}$ concentrations in cord blood differ. Dussault et al. (1969) found similar $\mathrm{T}_{3}$ values in maternal and cord blood. In later studies, however, low cord $\mathrm{T}_{3}$ values have been found (Hotelling and Sherwood, 1971; Larsen, 1972; Lieblich and Utiger, 1973). On the other hand, the plasma TSH, $\mathrm{T}_{4}$, and $\mathrm{T}_{3}$ concentrations are known to rise after birth (Fisher and Odell, 1969; Hüfner et al., 1973). It therefore seemed to be reasonable to measure the $T_{3}$ concentrations repeatedly after birth to compare with the serum $\mathrm{T}_{4}$ and $\mathrm{TSH}$ concentrations.

\section{Subjects and methods}

Blood samples were taken immediately after delivery from 10 mothers, from cord blood, and from the newborns at 1, 2, 6, 12, 24, and 48 hours. Blood samples were obtained by venepuncture with permission of the mothers, were allowed to clot, and the serum was then separated and stored at $-20^{\circ} \mathrm{C}$ until assayed. The mothers tested had no previous history of thyroid disease, and none was on medication in addition to taking vitamins and iron. Gestational age of their newborns ranged from 37 to 41 weeks (mean $39 \cdot 7$ weeks), birthweight from 3150 to $4180 \mathrm{~g}$ (mean $3753 \mathrm{~g}$ ),

^In the Editorial we wrote on 'The ethics of research involving children as controls', Archives, 1973, 48, 751, we mentioned that, 'we have sometimes invited an author to agree to our adding an editorial note to his paper, pointing out that there has been a difference of opinion on the ethical propriety of the publication', but that the authors have usually declined the invitation and withdrawn the paper. The authors of this study have availed themselves of such an invitation, and their letter on the subject is to be found on p. 575 of this issue. We are thus pleased to be able to publish both the results of their study and their, to us convincing, defence of its ethical propriety. Editors. and the Apgar scores at one minute from 7 to 10 (mean 8.4). $T_{3}$ was assayed by the direct immunoassay method (RIA-mat- $\mathrm{T}_{3}$-test ${ }^{\star}$ ), and the results are expressed as $\mu \mathrm{g} / \mathrm{l}$. The normal values of nonpregnant women are $0 \cdot 75-1 \cdot 65 \mu \mathrm{g} / 1 . \quad \mathrm{T}_{4}$ was assayed by the RES-O-mat- $\mathrm{T}_{4}$-test, ${ }^{\star}{ }^{\star}$ and the results are expressed as $\mu \mathrm{g} / \mathrm{l}$. The normal values of nonpregnant women are 65-175 $\mu \mathrm{g} / \mathrm{l}$. TSH in $200 \mu \mathrm{l}$ serum samples was estimated by the NIAMD human TIA method. Human TSH 63/68 from the Medical Research Council (England) was used as the standard, and expressed as mU/1. The binding of the label was significantly inhibited by $0 \cdot 2 \mu \mathrm{U}$. The normal values of nonpregnant women are $2-10 \mathrm{mU} / 1$ in our laboratory.

\section{Results}

Maternal serum $T_{3}$ and $T_{4}$ levels immediately after delivery were higher than those in healthy nonpregnant women, but serum TSH remained in the normal range (see Fig., left-hand columns). In the cord blood TSH was $5 \cdot 7 \pm 2 \cdot 2 \mathrm{mU} / 1$ (mean $\pm \mathrm{SD}$ ), increasing to $20 \cdot 6 \pm 6 \cdot 5 \mathrm{mU} / \mathrm{l}$ at 2 hours and then decreasing to the normal range within 12 hours. At age 48 hours TSH was already at a lower level $(2 \cdot 7 \pm 0.7 \mathrm{mU} / \mathrm{l})$ than at birth $(\mathrm{P}<0.001)$.

$\mathrm{T}_{3}$ concentration in cord blood was about one-third of the corresponding maternal blood value $(0.63 \pm 0.21 \mu \mathrm{g} / 1$ against $1.62 \pm 0.44 \mu \mathrm{g} / \mathrm{l}$; $\mathrm{P}<0.001$; Fig.). Soon after birth the $\mathrm{T}_{3}$ level of the neonates rose to the maternal level, reaching its maximum as early as at the age of 2 hours $(1 \cdot 76 \pm$ $0.34 \mu \mathrm{g} / \mathrm{l})$. Thereafter the $\mathrm{T}_{3}$ level dropped rapidly to the normal range (see Fig.).

Serum $\mathrm{T}_{4}$ concentration increased more slowly than that of the $T_{3}$ and was at its maximum at 24 hours $(205 \pm 15 \mu \mathrm{g} / \mathrm{l}$ against $145 \pm 27 \mu \mathrm{g} / \mathrm{l}$ at birth). At 48 hours serum $\mathrm{T}_{4}$ level $(202 \pm 17 \mu \mathrm{g} / \mathrm{l})$ was still significantly higher than that at birth.

\section{Discussion}

When the concentrations of thyroid hormones and TSH in the cord blood and newborn serum samples were compared with those of the mother, a biphasic change as a function of time could be shown. The hormone levels were low in the cord samples but high in the subsequent newborn

\footnotetext{
^Mallinckrodt Chemical Works, St. Louis, Missouri, USA.
} 


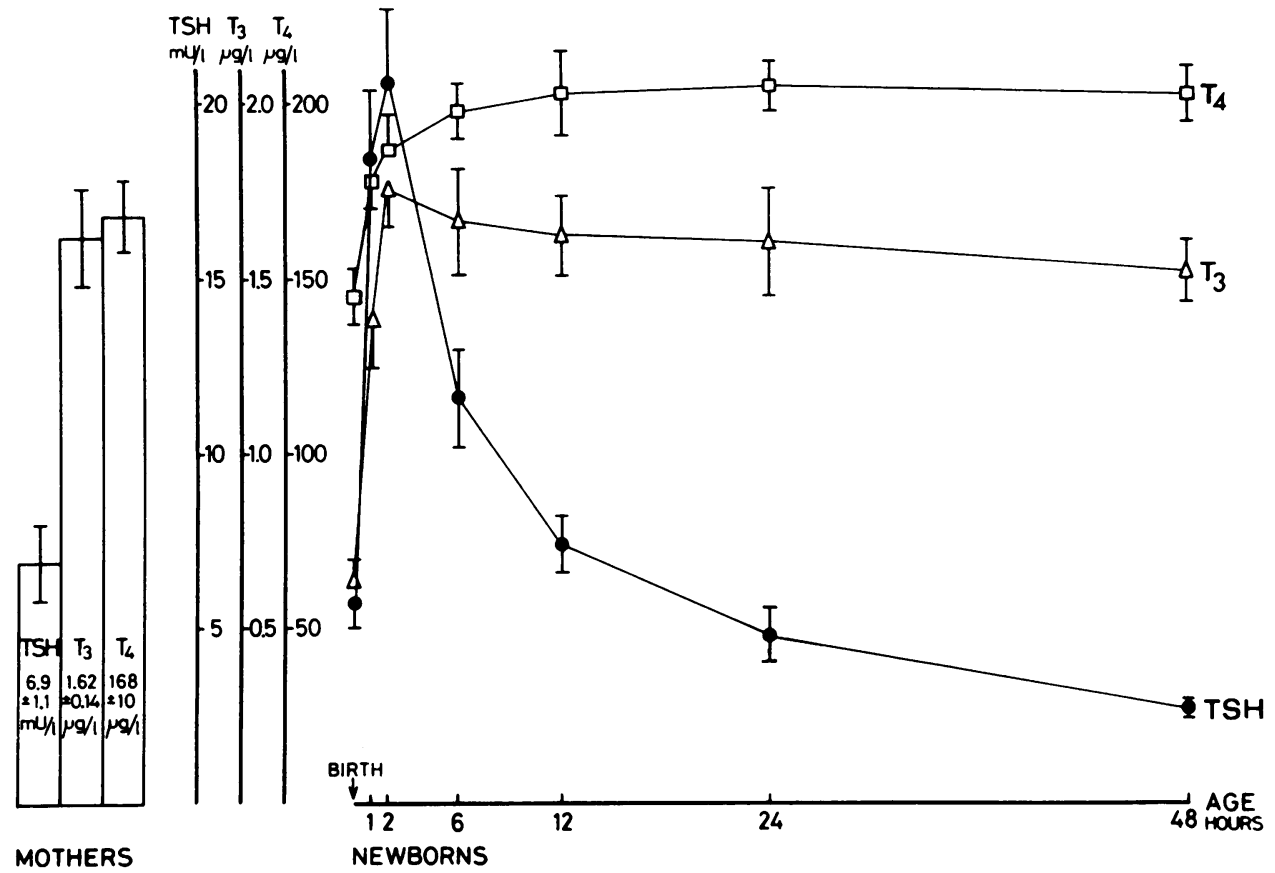

FIG.-Serum thyrotrophin (TSH), total tri-iodothyronine $\left(T_{3}\right)$, and total thyroxine $\left(T_{4}\right)$ concentrations (mean $\pm S E$ ) in maternal blood and in newborn infants at birth and during the first 48 hours of life.

samples. These results generally agree with previous findings (Hotelling and Sherwood, 1971; Larsen, 1972; Lieblich and Utiger, 1973; Hüfner et al., 1973).

The very low cord $T_{3}$ levels found in this study agree with most previous reports (Hotelling and Sherwood 1971; Larsen, 1972; Lieblich and Utiger, 1973; Hüfner et al., 1973). The present results offer no explanation for the finding, but the following assumptions are feasible. (1) Extrathyroideal conversion from $T_{4}$ to $T_{3}$ is decreased. (2) The amount of specific $T_{3}$-binding proteins in the cord serum is reduced. (3) The distribution volume to $T_{3}$ is increased. (4) The formation of $T_{3}$ by the fetal thyroid is decreased. The $T_{3}$ level of fetal serum recently has been shown to be low in the human fetus (Fisher et al., 1973), which favours the first or the last alternative. Fisher et al. (1973) found the ratio of $T_{4} / T_{3}$ content of 14 human fetal thyroid glands to be similar to that of adult glands, concluding either that the fetus cannot convert $T_{4}$ to $T_{3}$ at a rate comparable to the adults, or that $T_{4}$ is unavailable for such conversion.

Fisher and Odell (1969) showed that the umbilical cord plasma TSH concentration is more than twice as high as that found in the mother at term. How- ever, we could not find any statistically significant difference in these samples, and the cord TSH values tended to be even lower than the maternal ones. In our subsequent samples the serum TSH level increased markedly (over $300 \%$ ), reaching a maximum at 2 hours and declining to subnormal values at 48 hours, evidently due to the raised secretion of thyroid hormones.

After birth serum $\mathrm{TSH}$ and $\mathrm{T}_{3}$ concentrations rose sharply and concurrently, reaching maximum at 2 hours. It is believed that the increase of TSH secretion is due to the decrease of environmental temperature (Fisher and Odell, 1969). The cause of the simultaneous increase of $\mathrm{T}_{3}$ secretion remains unknown. It is, however, generally known that TSH-dependent secretion of thyroid hormones occurs clearly after the TSH release.

The measurement of TSH (and possibly $\mathrm{T}_{3}$ and $T_{4}$ ) in cord serum or immediately after birth has proved to be a reliable technique of screening for congenital hypothyroidism (Klein, Agustin, and Foley, 1974). Because there are great, rapid physiological changes in the serum concentrations of $\mathrm{T}_{3}, \mathrm{TSH}$, and $\mathrm{T}_{4}$ during the first 12 hours of life, we recommend that screening should be carried out at the age of 24 hours or after. 


\section{Summary}

The serum concentrations of tri-iodothyronine $\left(T_{3}\right)$, thyroxine $\left(T_{4}\right)$, and thyrotrophin (TSH) were measured in 10 term newborn infants between birth and the age of 2 days by radioimmunoassay. The mean concentration of $T_{3}$ in maternal serum was $1.62 \mu \mathrm{g} / \mathrm{l}$, and it increased from the low cord blood level of $0.63 \mu \mathrm{g} / 1$ to the peak value of 1.76 $\mu \mathrm{g} / 1$ within the first 2 hours of life. Mean serum $\mathrm{T}_{4}$ concentrations increased from the cord blood level of $145 \mu \mathrm{g} / 1$ to the peak value of $205 \mu \mathrm{g} / 1$ within the first 24 hours of life. The postnatal increase of the mean serum TSH concentrations from the cord blood level of $5 \cdot 7 \mathrm{mU} / 1$ to the peak value of $20.6 \mathrm{mU} / 1$ within 2 hours was similar to the increase of $T_{3}$.

These data confirm earlier reports which show that $\mathrm{T}_{3}$ secretion is low at birth and TSH secretion is stimulated strongly but transiently after birth, and that the low $\mathrm{T}_{3}$ secretion is rapidly normalized in 2 hours along with the TSH release. Because of these strong and rapid changes, we recommend screening of the function of the pituitary-thyroid axis in neonates after the age of 24 hours.

\section{REFERENCES}

Dussault, J., Row, V. V., Lickrish, G., and Volpé, R. (1969). Studies of serum triiodothyronine concentration in maternal and cord blood: transfer of triiodothyronine across the human placenta. Fournal of Clinical Endocrinology and Metabolism, 29, 595.

Fisher, D. A., and Odell, W. D. (1969). Acute release of thyrotropin in the newborn. Fournal of Clinical Investigation, 48, 1670.

Fisher, D. A., Dussault, J. H., Hobel, C. J., and Lam, R. (1973). Serum and thyroid gland triiodothyronine in the human fetus. fournal of Clinical Endocrinology and Metabolism, 36, 397.

Hotelling, D. R., and Sherwood, L. M. (1971). The effects of pregnancy on circulating triiodothyronine. Fournal of Clinical Endocrinology and Metabolism, 33, 783.

Hüfner, M., Hesch, R.-D., Heinrich, U., and Lüders, D. (1973). Plasma triiodothyronine at the end of pregnancy, in the cord blood and in the first days of the newborn. Zeitschrift fïr Kinderheilkunde, 114, 301.

Klein, A. H., Agustin, A. V., and Foley, T. P., Jr. (1974). Successful laboratory screening for congenital hypothyroidism. Lancet, $2,77$.

Larsen, P. R. (1972). Direct immunoassay of triiodothyronine in human serum. Fournal of Clinical Investigation, 51, 1939.

Lieblich, J. M., and Utiger, R. D. (1973). Triiodothyronine in cord serum. Fournal of Pediatrics, 82, 290.

\section{S. SIMILÄ, ${ }^{\star}$ M. KoIvisto, T. RANTA, J. LEPPÄLUOTO,} M. REINIL $\ddot{\text {, }}$ and J. HaApalahti

Departments of Paediatrics and Physiology, University of Oulu; Department of Physiology, University of Helsinki; and Isotope Laboratory of Deaconess Institute, Oulu, Finland.

*Correspondence to Dr. S. Simila, Department of Paediatrics, University of Oulu, SF-90220 Oulu 22, Finland.

\section{Raised serum TSH in hypothyroidism}

Hypothyroidism is a graded phenomenon; at one end of the spectrum the symptoms and clinical features are overt, at the other end they may be so mild as to escape clinical detection. In paediatric practice a good case can be made for the desirability of detecting early hypothyroidism of the mildest degree but hitherto lack of specific symptoms and the fact that conventional tests of thyroid function may be normal for a variable period of time have delayed the diagnosis.

Recently it has become possible to assay the serum thyroid stimulating hormone (TSH) concentration (Hall, 1972), and it is now accepted that patients with mild hypothyroidism have a raised serum TSH. Conversely, thyroid insufficiency can be confidently excluded if the serum TSH concentration is normal.

Normal serum TSH values range from undetectable to $4 \mu \mathrm{U} / \mathrm{ml}$ (Hall and Evered, 1973) but since this is a relatively new assay, laboratories must determine the specificity and accuracy of the test in their hands as well as establish their range of normal values. There are, however, no significant differences in TSH levels in men, women, or children after the neonatal period. High values for serum TSH almost certainly reflect a reduction in the circulating levels of thyroxine $\left(\mathrm{T}_{4}\right)$ and triiodothyronine $\left(\mathrm{T}_{3}\right)$ but by an instant reciprocity the increased TSH output may maintain, at least for a time, $T_{4}$ and/or $T_{3}$ levels within the range which will prevent a state of overt hypothyroidism.

In this case report we draw attention to the importance of serum TSH assay when suspicion of hypothyroidism is aroused, even though conventional tests of thyroid function are normal.

\section{Case report}

A female (born 4 February 1968) is the second child of healthy unrelated parents. She presented in January 1970 at the age of 1.9 years because of shortmess of stature. Since the age of 1 year the parents had been concerned because of her failure to grow. There was a history of constipation but no lethargy or preference for warm weather. Clinically (height $78 \mathrm{~cm}$, weight $9.9 \mathrm{~kg}$ ) she was small and alert and apart from fine sparse hair there were no other positive features of disease. Bone age was 1 year, epiphyseal dysgenesis was absent, serum cholesterol was $169 \mathrm{mg} / 100 \mathrm{ml}(4 \mathrm{mmol} / \mathrm{l})$ and protein-bound iodine $6.0 \mu \mathrm{g} / 100 \mathrm{ml}(472 \mathrm{nmol} / 1)$.

She was seen regularly during the following 18 months during which period constipation persisted and also growth failure. In June 1972 at the age of 2.4 years the serum cholesterol was $245 \mathrm{mg} / 100 \mathrm{ml}(6.35 \mathrm{mmol} / \mathrm{l})$, 